\title{
Epilepsy, Progressive Myoclonic 7
}

National Cancer Institute

\section{Source}

National Cancer Institute. Epilepsy, Progressive Myoclonic 7. NCI Thesaurus. Code C142804.

An autosomal dominant form of early progressive myoclonic epilepsy, caused by mutation(s) in the KCNC1 gene, encoding potassium voltage-gated channel subfamily C member 1. 